\title{
COMPARATIVE INCIDENCE OF HELMINTH PARASITES IN DOMESTIC FOWL, WHITE LEG HORNE, LAYER AND COCK
}

\author{
Rimi Farhana Zaman, Ameena Khatun, Shahela Alam, \\ Farhana Muznebin ${ }^{1}$ and Hamida Khanum* \\ Department of Zoology, University of Dhaka, \\ Dhaka-1000, Bangladesh
}

\begin{abstract}
Investigation on gastrointestinal helminths was conducted on 20 domestic fowl, 20 white leghorn, 20 layer and 20 cock of Dhaka city. Six species of helminth belonging to trematode, cestode and nematode were found to infect the different parts of alimentary canal of domestic fowl. The prevalence of helminths in domestic fowl were as follows: Catatropis verrucosa (25\%), Amoebotaenia sphenoides (10\%), Hymenolepis cantaniana (35\%), Rallietina echinobothrida (55\%), Ascardia galli (70\%) and Heterakis gallinarum (30\%) whereas, in white leghorn the prevalence of Rallietina echinobothrida (20\%) and Ascardia galli (35\%) were recorded. In layer, higher prevalence of Rallietina echinobothrida (55\%) and Ascardia galli (60\%) were recorded; in cock the prevalence of specific helminthes were as follows: Hymenolepis cantaniana (10\%), Rallietina echinobothrida (40\%), Cotugnia digonopora (20\%), Ascardia galli (60\%) and Heterakis gallinarum (25\%). Along with the prevalence and intensity of infestation of different species of parasites, intensity were also recorded. Highest number of parasites were collected from intestine.
\end{abstract}

Key words: Parasites, helminth, fowl, layer, cock

\section{INTRODUCTION}

Certain ecological traits of vertebrate host could facilitate parasite colonization or within host speciation, creating differences in parasite species richness among host taxa and obscuring the influence of co-speciation. These ecological parameters determine to some extent the likelihood that hosts encounter and are colonized by new parasite species as well as the diversity of riches available to parasites (Paulin 1995). The patterns above reflect the distribution of parasite diversity among host species with respect to host features, not necessarily the rates of parasites diversification within these intestinal parasites of vertebrates, genera represented by two or more species (Kennedy and Bush 1992). The diversity of species in a given habitat depends upon the probabilities of the properties of the habitat (Hassouni and Belghyti 2006, Molla et al. 2012). Pattern in the diversity of parasites may be associated with either host or parasites' characteristics. This may determine the likelihood that hosts are colonized by parasite species over evolutionary time (Shinde et al. 2004, 2009).

*Author for correspondence: hamida_khanum@yahoo.com 1Department of Zoology, Jagannath UniversityDhaka, Bangladesh.

(c) 2016 Zoological Society of Bangladesh DOI: 10.3329/bjz.v44i2.32764 
Parasitism results into morbidity and mortality in tropical countries, particularly in the socio-economically under developed societies in the world. These types of parasites affect not only human health but also livestock, poultry, fishes and crops etc. Parasitic infection of livestock, poultry, fishes; crops are major ailments impend the development of these industries in Bangladesh (Yadav and Tandon 1991). The most commonly kept poultry are chickens (Gallus sp.), ducks (Cairina sp.), geese (Anser sp.) and turkeys (Meleagris sp.). Among these, domestic chickens (Gallus domesticus) are the most (FAO 2007, Mekibib et al. 2014). Compared to a number of other livestock species, fewer social and religious taboos are related to the production, marketing and consumption of poultry products. For these reasons poultry products have become one of the most important protein sources for man throughout the world (Abdul-Hamed 1984, Bhure et al. 2013). Commercial hybrids are used by the commercial system, while the village system makes use of indigenous or local breeds. Indigenous chickens appear to have an inherent scavenging and nesting habit (Minga et al. 2004).

Poultry meat production developed from numerous small broiler farms into a well-defined global broiler industry (Baboolal et al. 2012). The increasing demand for poultry meat and eggs in many parts of the developing world favours the industrialization of production systems (Khanum and Ahmed 1997). The poultry sector is the most industrialized of all forms of livestock production, and large-scale production is now widespread in many developing countries. In spite of farming and supplying processed food to poultry, a huge burden of parasites are observed in poultry of Bangladesh.

The domestic chicken is exposed to environmental condition which involves a high risk of parasitism. Poultry basically scavenger and subsists on waste grains and other foods like worms, maggots, insects, cow/buffalo dung, kitchen waste, viscera of other animals etc. Humans get automatically infected at the time of eating the infectious and uncooked flesh of chickens. Birds, like all other animals, too suffer from a wide range of maladies (Rahman et al. 1989). Birds having access to outdoor areas have a greater diversity of ecto and endoparasites (Pandey et al. 1992, Dar and Tanveer 2013, Khanum 1997). Gastrointestinal parasites constitute a major factor limiting productivity of the poultry industry by affecting the growth rate of the host results in malfunctioning to organs and eventually death. The parasitic diseases occur due to the infection of nematode parasites such as Stronglyloides sp., Capillaria annulata, Heterakis spp., Ascardia galli, etc. Among trematodas mostly found parasites are Echinostama revolutum, Prosthogoinous vitellatus, Catatropis verracosa and among cestoda mostly found parasites are Cotugnia digonopora, 
Raillietina echinobothridia, Hymenolepis rustica etc. (Khanum 1974). Epidemiological studies on the prevalence of important parasitic diseases in poultry would provide strategic and tactical principles of parasite control. But epidemiological research on the prevalence of parasitic diseases is scanty and haphazard in Bangladesh.

\section{MATERIAL AND METHODS}

The study was conducted from March 2013 to February, 2014. The host animals were domestic fowl, white leghorn, layer and cock. These chickens were collected from New Market and Polashi bazaar of Dhaka city.

Trematode, cestode and nematode were fixed (Cheeshbrough 2004) were fixed with favorable both in alcohol-formal-acetic (A. F. A.) and glacial acetic acid. Both the fixatives were used in hot condition; the only clearing agent lactophenol was used for trematodes. The worms were studied as temporary where mounts in lactophenol. Staining the worms were needed, the worms were dropped in a considerable amount of borax carmine without being diluted with lactophenol. In the present observation, collected parasites were identified according to the descriptions and figures given by Yamaguti $(1958,1959,1961)$, Soulsby (1969), Cheng (1985), Khanum (1974).

\section{RESULTS AND DISCUSSION}

It has been observed that the intensity of cestode parasite was high compared to other groups. From 20 domestic fowl 250 parasites were collected from the digestive tract, among them, 24 were trematode, 148 cestodes and 78 nematodes. The percentage of each parasitic groups were; trematode 9.6, cestodes 59.2, nematodes 78 .

Prevalence and intensity of helminth parasites in domestic fowl: The prevalence of trematode group was the lowest among helminth infestation in domestic fowl. The prevalence of Catatropis verrucosa was $25 \%$ and the intensity was 4.8. Cestodes were common parasites in domestic fowl. All of the fowls were infected either by one or more species of cestodes. Three species of cestodes were recorded from domestic fowl, Rallietina echinobothrida was the common species of cestodes. Prevalence of each cestode parasites was Amoebotaenia sphenoides at 10\%, Hymenolepis cantaniana at $35 \%$ and Rallietina echinobothrida at $55 \%$. The intensiy of Hymenolepis cantaniana at $7.57 \pm 1.8$ (Sd), was highest. The intensity of other cestodes were; Amoebotaenia sphenoides at $1.5 \pm 0.5$ (Sd) and Rallietina echinobothrida at $6.90 \pm 2.2$ (Sd).

Nematodes were also common parasites of domestic fowl. In this observation 
two species of nematodes were found, Ascardia galli was the most common nematode parasite of domestic fowl. The prevalence of Ascardia galli was at $70 \%$ and intensity was at $2.5 \pm 1.2 \mathrm{Sd}$ ). The prevalence of Heterakis gallinarum was $30 \%$ with $43 \pm 2.5$ intensity (Fig. 1). Correlation (r) between prevalence and intensity $(\mathrm{r}=0.101, \mathrm{p}=0.850)$.

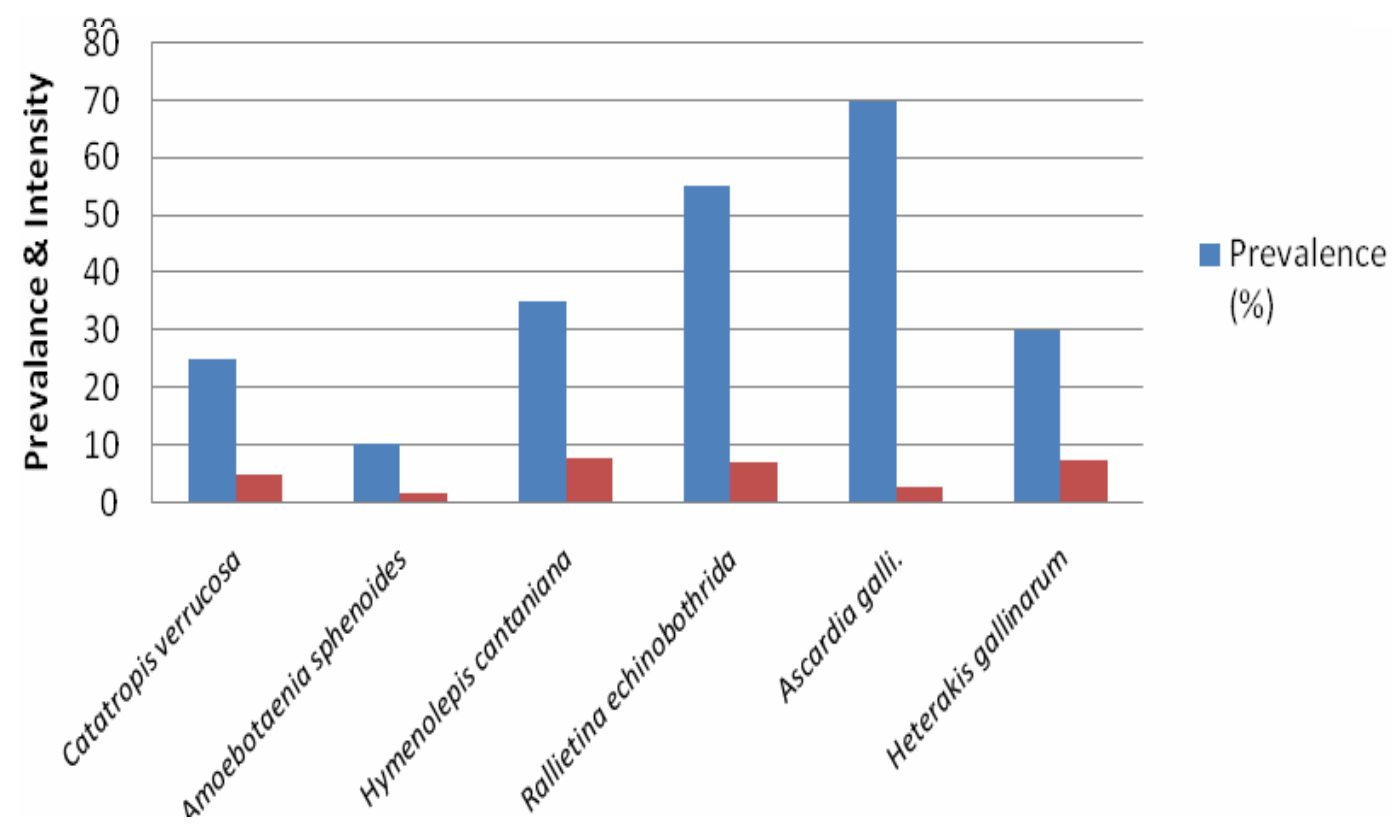

Fig. 1. Prevalence and intensity of helminth infestation in domestic fowl.

Prevalence and intensity of helminthes infestation in white leghorn: In white leghorn, prevalence and intensity of helminth parasites were low. Only Rallietina echinobothrida and Ascardia galli were recorded in whire legorn. Out of 20 only four hosts were infected by $R$. echinobothrida and the prevalence and intensity was accordingly $20 \%$ and $4 \pm 1.2$. The prevalence of Ascardia galli was $35 \%$ and the intensity was $2.71 \pm 0.8$ (Fig. 2). Helminth infestation in white leghorn was very low. Total number of parasites were 35, among them cestodes were 16 and nematodes were 19 . The percentage of cestodes and nematodes were accordingly 45.71 and 54.29. The p-value of cestodes and nematodes was (0.6164, $\mathrm{p}>0.1)$ which was insignificant.

Prevalence of different parasitic groups in layer: It has been observed that in layer only cestodes and nematodes are found. Total number of parasites was 149. Among them cestodes were 122 and nematodes were 27. Percentage of cestode group was 81.88 and the percentage of nematode group was 18.12 . In 
layer, intensity of helminth parasites were low and Rallietina echinobothrida and Ascardia galli were collected from layer. Out of 20 layer examined, only 11 hosts were infected by Rallietina echinobothrida. The prevalence and intensity of Rallietina echinobothrida were accordingly 55\% and $11.09 \pm 2.4$. The prevalence of Ascardia galli was $60 \%$ and the intensity was $25 \pm 0.8$.

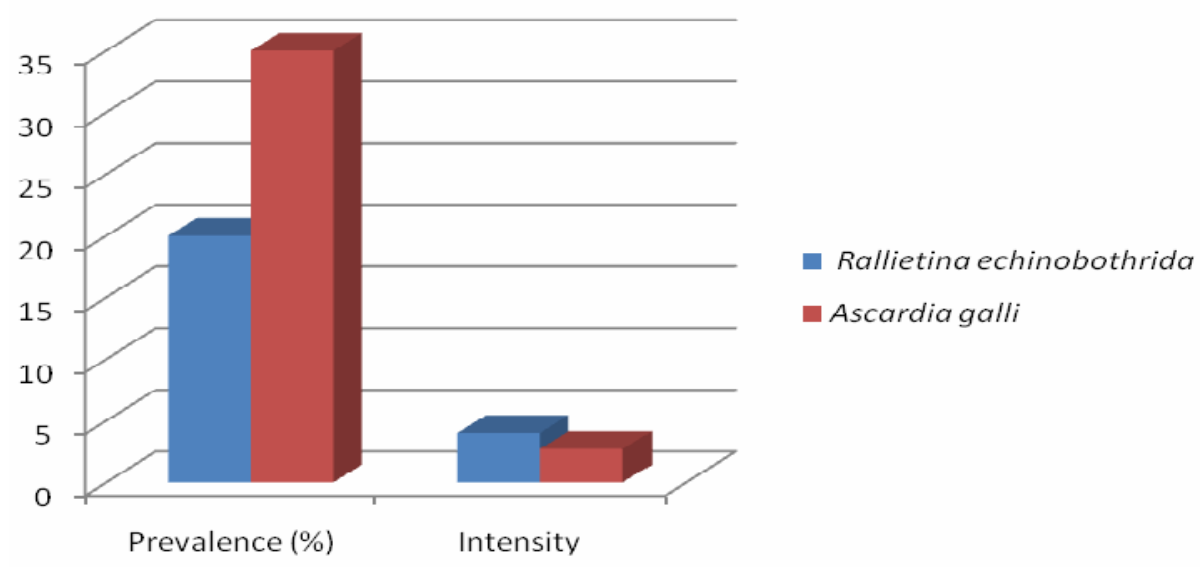

Fig. 2. Prevalence and intensity of helminthes infestation in white leghorn.

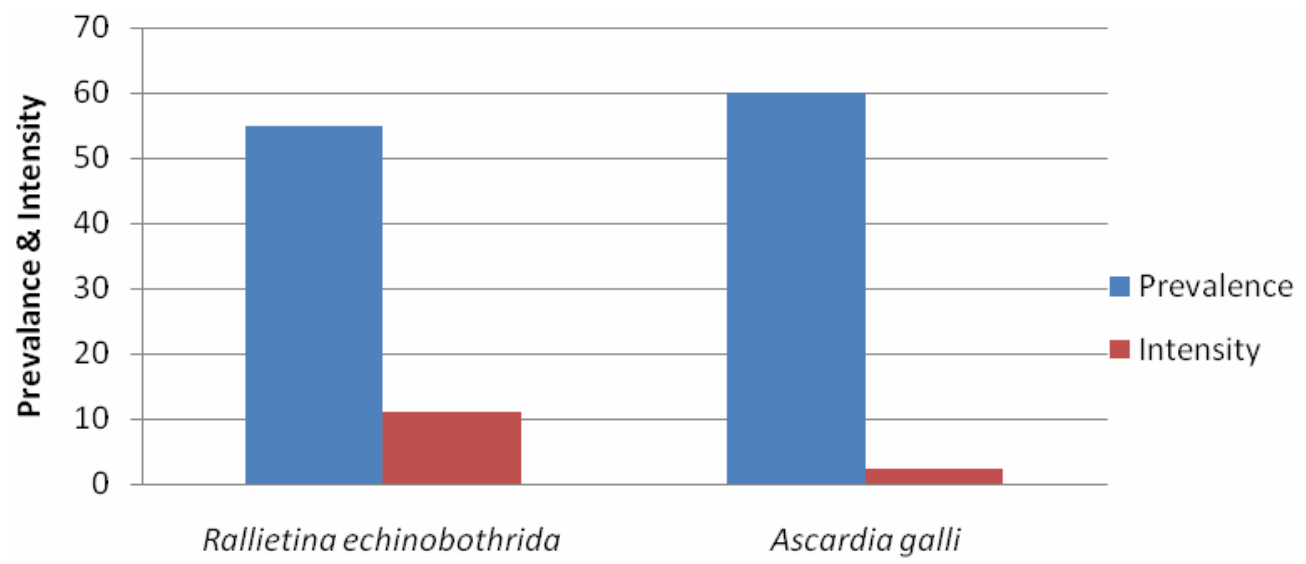

Fig. 3. Prevalence and intensity of helminth infestation in layer.

Prevalence and intensity of helminth infestation in cock: Cestodes were common parasites in cock. All of the observations were infected either by one or more species of cestodes. Rallietina echinobothrida was the common species of cestodes. Prevalence of each cestode parasites were Hymenolepis cantaniana (10\%), Rallietina echinobothrida (40\%) and Cotugnia digonopora (20\%). The 
intensiy of Rallietina echinobothrida $(11.87 \pm 2.8)$ was highest. The intensity of other cestodes were; Hymenolepis cantaniana (11.5 \pm 2.5$)$ and Cotugnia digonopora $(4.25 \pm 1.2)$.

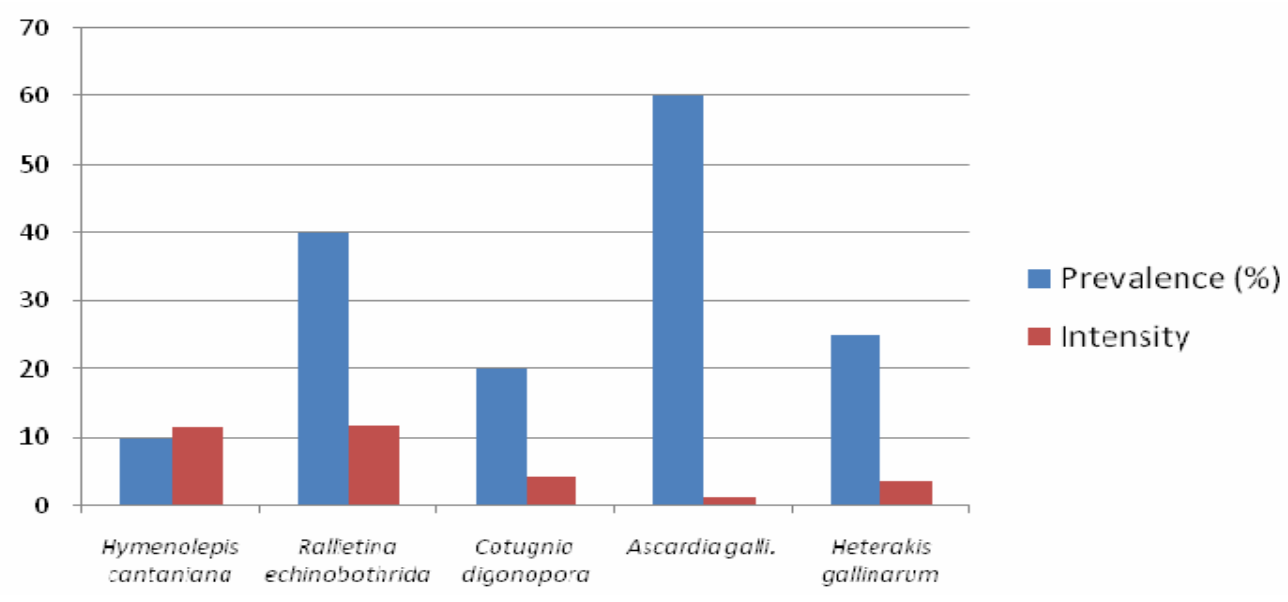

Fig. 4. Prevalence and intensity of helminth infestation in cock.

Organal distribution of helminth parasites in domestic fowl: Six species of helminths were collected from different parts of the digestive tract. Highest number of parasites were collected from intestine. Three species (two cestode and one nematode) were recorded from intestine. Amoebotaenia sphenoides was observed in both duodenum and intestine. Catatropis verrousa was collected from caecum and rectum. No helminthes were in proventriculus and rest of the parts of digestive tract. Only two species were collected from white leghorn. The recorded species were $R$. echinobothrida and Ascardia galli. These species were recorded from intestine. No helminthes were found in proventriculus and rest of the parts of digestive tract.

Organal distribution of helminth parasites in layer and cock: Only two species were collected from layer. The recorded species were Rallietina echinobothrida and Ascardia galli. These species were recorded from intestine. No helminthes were found in proventriculus and rest of the parts of digestive tract. Five species of helminths were collected from different parts of the digestive tract. Highest number of parasites were collected from intestine, Cotugnia digonopora, Hymenolepis cantaniana and Rallietina echinobothrida were recorded from intestine Ascardia galli was observed in both duodenum and intestine. Heterakis gallinarum was collected from caecum. No helminthes were observed in proventriculus and rest of the parts of digestive tract. 
Organal distribution of helminth parasites in white leghorn: Only two species were collected from layer. The recorded species were Rallietina echinobothrida and Ascardia. No species were recorded from upper part of the alimentary canal such as oesophagus, crop, proventriculus and gizzard. Most of the parasites were restricted to the small intestine, particularly the duodenum where there is optimum concentration of saline and glucose (Fatihu et al. 1991). While, Khanum (1974) reported 21 species of helminthes from different parts of the digestive tract including crop, caecum and rectum. Pal et al. (1985) examined 1568 intestine of domestic fowl and reported that $80.61 \%$ were infected with helminthes in Punjab (Pakistan). Ilyes et al. (2013) reported 88.19\% prevalence of helminth parasites in his work in Algeria. Rabbi et al. (2006) worked on gastrointestinal helminthes infection in different types of poultry and reported prevalence of different species of gastrointestinal helminths was highest in backyard poultry $(100 \%)$ followed by layer $(48.75 \%)$ and broiler $(3.75 \%)$. In the present observation, the prevalence of gastrointestinal helminths were highest in backyard poultry $(75 \%)$ and cock chicken $(75 \%)$, layer hen $(65 \%)$ and lower in broiler (35\%).

Comparison on helminth infestation between domestic fowl, white leghorn, layer hen and cock: The result of this study showed that the domestic fowl were heavily parasitized. Mixed infections were also encountered and most with nematode. Yoriyo et al. (2005) reported high prevalence of the helminth parasites. Previous studies have attributed this high endemicity to poor sanitary conditions and lack of health services (Eshetu et al. 2001). In the present study, Ascaridia galli having a remarkable prevalence of $70 \%$ and this is in agreement with earlier findings of Yoriyo et al. (2008). The reasons being that nematodes generally do not require intermediate hosts and at the same time they are soil transmitted parasites. Lower prevalence of helminth infestation and a few number of parasites in white leghorn and layer chicken is expectable because they are reared in a confinement, served processed food and in hygienic condition,

The differences in the worm burden could be attributed to climate difference, availability of intermediate host, and possibly host factors such as host immunity (Khanum 1987). Parasitic intervention to limit hallmark complication of the infection is thus necessary in poultry industries. Zabbar (1992) reported that infection of trematode were - 46\% while, cestodes and nematodes $100 \%$. Ashenafi et al. (2004) reported that prevalence of cestodes were $-86.32 \%$ and nematodes $75.79 \%$ in local chicken of central Ethiopia.

The parasitic infection in hosts depends on different factors e.g. pH, temperature, availability of suitable intermediate hosts, flora, water, etc. This is 
obviously more true in the case of parasitic infestation which involve intermediate hosts. In all present seasons suitable intermediate hosts are not available.

\section{CONCLUSION}

As domestic fowls are exposed to natural environment and adapted to variety of foods and lives in non hygienic and contaminated conditions, they are easily infected by parasites. Digested or partially digested foods of the hosts are shared by different species of helminthes, but white leghorns, layer chicken and cock chicken in farm are served of controlled foods and pure drinking water, so there is less chances for parasitic infestation. If the domestic fowls are domesticated in such a way like farm poultry there is possibility to prevent the loss of protein which occurs due to helminth infection.

\section{LITERATURE CITED}

ASHENAFI, H. and ESHETU, Y. 2004. Study on gastrointestinal helminths of local chickens in central Ethiopia. Rev. Med. Vet.. 155:504-507.

ABDUL-HAMED, S.N. 1984. Studies on the effect of host dietary factors on the host-parasite relationship between Heterakis gallinarum (Nematoda: Heterakidae) and the chicken. Dissertation Abst. Int. 45: 735-73.

BABOOlal, V., SURATSINGH, V., GYAN, L., BROWN, G., OFFIAH, N. V., ADESIYUN, A. A. and BASU, A. K. 2012. The prevalence of intestinal helminthes in broiler chickens in Trinidad. Vet. Arhiv. 82: 591-597.

BHURE, D. B. , NANWARE, S. S. and SUNNAP, N. V. 2013. Status of Diversity of Cestode Parasites of Domestic Fowl (Gallus gallus domesticus) from Nanded district, Maharastra state. Indian Journal of Applied Research 3(10): 25-28.

CHENG, T. C. 1985. General Parasitology. W. B. Saunders Company. pp. 125-130.

CHEeshbrough, M. 1987. Medical Laboratory Manual for Tropical Countries. Vol. 1. ELBS. University press, Cambridge. 605 pp.

DAR, J. A. and TANVEER, S. 2013. Prevalence of cestode parasites in free-range backyard chicken (Gallus gallus domesticus) of Kashmir, India. Agric. Biol. J. N. Am. 4(1): 67-70.

ESHETU, Y., MULUALEM, E., IBRAHIM, H., BERHANU, A. and ABERRA, K. 2001. Study of Gastrointestinal helminths of scavenging chicken in four districts of Amhara Region, Ethiopia. Rev. Sci. Tech. 20: 791-796.

FAO March 1987. (Food and Agricultural Organization of the United Nations), "Report on the expert consultation on rural poultry development in Asia, Dhaka, Bangladesh," Tech. Rep. 274415, FAO, Rome, Italy.

FAO. 2007. The State of the World's Animal Genetic Resources for Food and Agriculture, edited by B. Rischkowsky \& D. Pilling. Rome.

HASSOUMI, T. and BELGHYTI, D. 2006. Distribution of gastrointestinal helminths in chicken farms in the Gharb region - Morocco. Parasitol. Res. 99: 181-183. 
HUSSEN, H., CHAKA, H., DENEKE, Y. and BITEW, M. 2012. Gastrointestinal helminths are highly prevalent in scavenging chickens of selected districts of eastern Shewa zone, Ethiopia. Pakistan Journal of Biological Sciences 15: 284-289.

ILES, M. and AHMED, B. 2013. Cestode parasites of free-range chickens (Gallus gallus domesticus) in the North-Eastern of Algeria. International Journal of Poultry Science 12(11): 681- 684.

KHANUM, H. 1974. Studies on some helminthes of domestic fowl of Dhaka city. M. Sc. Thesis. $1-163 \mathrm{pp}$.

KHANUM, H. 1987. Gastrointestinal Nematodes from domestic fowl. Bangladesh J. Zool. 5(2): 155-159.

KHANUM, H. 1997. Trematode parasite Parymphistomum humairum n. sp. species from domestic fowl of Bangladesh. Journal of Bengal Natural History 16(2): 35-39.

KHANUM, H. and AHMED, Z. 1997. Comparative study of Helminth faune and rate of infestation in domestic fowl and reared white leghorn. J. Sci. Res. 15(2): 187-191.

KENNEDY, C. R. and BUSH, A. O. 1992. Species richness in helminth communities; the importance of multiple congeners. Parasitology 104: 189-197.

MEKIBIB, B., DEJENE, H. and SHEFERAW, D. 2014. Gastrointestinal Helminthes of scavenging chickens in outskirts of Hawassa, southern Eithiopia. Global veterianaria 12(4): 557-561.

MINGA, U. M., Msoffe, P. L. and Gwakisa, P. S. 2004. Biodiversity (variation) in disease resistance and in pathogens within rural chickens. In Proceedings of XXII World's Poultry Congress, June 8-12, 2004, Istanbul, Turkey.

MOLlA, W., HAILE, H., ALMAW, G. and TEMESGEN, W. 2012. Gastrointestinal Helminthes of local backyard chickens in North Gondar Administrative Zone, Ethiopia. Revue Med. Vet. 7: 362-367.

MUnGuBE, E. O., BAUni, S. M., TENHAGEN, B. A., WAMAE, L. W., NZIOKA, S. M., MUHAMMED, L. and NGINYI, J. M. 2008. Prevalence of parasites of the local scavenging chicken in a selected semi-arid zone of eastern Kenya. Trop. Anim. Health Prod. 40: 101-109.

NAEM, S. and ESKANDARI, S. 2005. Prevalence of intestinal Helminths of native chickens in Urmia Iran. Iranian 3(2): 200 - 203.

PERMin, A., MAGWiSha, H., KASSUKU, A. A., NANSEN, P., BISGAARD, M., FRANDSEN, F. and GIBBONS, L. 1997. A cross-sectional study of Helminths in rural scavenging poultry in Tanzania in relation to season and climate. J. Helminthology 71(3): 233-240.

PAL, R.A. and AHMED, K.N. 1985. A survey of intestinal Helminths of poultry in some districts of the Punjab and N.W.F.P. Pakistan J. Zool. 17(2): 193-200.

PANDEY, V.S. 1992. Epidemiolgy and economics of village poultry production in Africa 124-128.

PAULIN, R. 1995. Phylogeny, ecology and the richness of parasite communities in vertebrates. Ecological Monographs 65: 283- 302.

RABBI, A. K. M. A., ISLAM, A., MAJUMDER, S., ANISUZZAMAN, A. and RAHMAN, M.H. 2006. Gastrointestinal Helminthes infection in different types of poultry. Bangla. J. Vet. Med. 4(1): 13-18.

RAHMAN, M., SORENSEN, P., JENSEN, H. A. and DOLBERG, F. 1997. Exotic hens under semiscavenging conditions in Bangladesh. Livestock Research for Rural Development 9: 1-11.

SHINDE, L. V., DESHMUKH, S. B. and GORE, G. D. 2004. Population of gastrointestinal nematode in Gallus gallus domesticus at Beed, Maharastra. Uttar Pradesh Journal of Zoology 24(2): 213215.

SHINDE, L., JADHAV, B. and LANKA, L. P. 2009. Ecological survey of endoparasites from alimentary canal of Gallus gallus domesticus at Bhokardan dist. Jalna (M.S.). Deccan Current Science 11: 23-30.

WAKELIN, D. 1964. A survey of the intestinal Helminthes parasitic in British domestic fowl. Journal of Helminthology 28: 191-210. 
YADAVA, A. K. and TANDON V. 1991. Helminth parasitism of domestic fowl (Gallus domesticus L.) in a subtropical high-rainfall area of India. Beitr. Trop. Landwiirtsch. Vet. Med. 29: 97-104.

YAMAGUTI, 1958. Systema Helminthum. The digenetic Trematodes of Vertebrates part I and II. Vol. 1. Interscience Publishers.

YAMAGUTI 1959. Systema Helminthum. The Cestodes of Verrtebrates. Vol. II. Interscience Publishers.

YAMAGUTI, 1961. Systema Helminthum. The Nematodes of Verrtebrates. Part I and II. Vol. III. Interscience Publishers.

YAMAGUTTI, S. 1961. Systema Helminthum Vol. III. The Cestode parasites of Vertebrates. Intersciences Publishers, New York.

YORIYO, K. P. ADANG, K.L., FABIYI, J. P. and ADAMU, S. U. 2008. "Helminth parasites of local chickens in Bauchi state Nigeria," Science World Journal 3(2): 35-37.

ZABBAR, A. 1992. Studies on gut Helminthes of domestic fowl and leghorn. M.Sc. thesis. pp.137.

(Manuscript received on 10 January, 2016; revised on 29 December, 2016) 